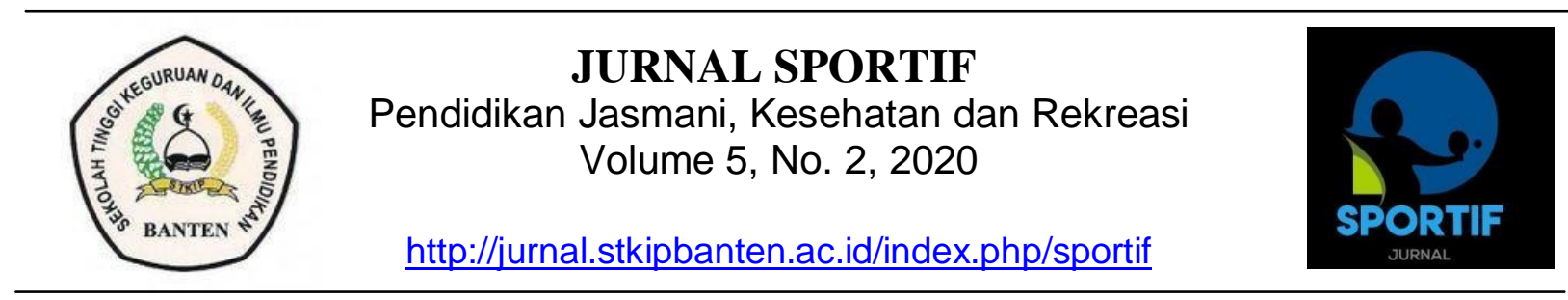

\title{
LATIHAN MASSED PRACTICE MELALUI KETERAMPILAN PUKULAN SMASH BULUTANGKIS
}

\author{
Ahmad Yanuar Syauki, Endrik ${ }^{2}$ \\ ${ }^{1}$ Sekolah Tinggi Keguruan dan Ilmu Pendidikan Banten \\ ${ }^{2}$ Mahasiswa, Pendidikan Jasmani, Kesehtan dan Rekreasi \\ aysyauki@yahoo.com, ${ }^{2}$ endrikcool11@gmail.com
}

\begin{abstract}
ABSTRAK
Proses pembentukan sikap dan pembangkitan motivasi harus dimulai pada usia dini, tujuan penelitian ini adalah untuk mengetahui pengaruh metode latihan massed practice terhadap terhadap keterampilan smash bulutangkis. Metode penelitian yang digunakan adalah penelitian studi literatur yang terdiri dari beberapa sumber seperti sumber primer dan sumber sekunder. Berdasarkan hasil penelitian yang telah dilakukan peneliti berupa analisa sumber-sumber yang relevan berupa jurnal maupun buku, maka peneliti menemukan bahwa metode latihan massed practice dapat meningkatkan keterampilan smash bulutangkis. Pernyataan ini didukung oleh berbagai penelitian terdahulu yang memperoleh peningkatan teknik keterampilan smash ketika menerapkan metode latihan massed practice dalam kegiatan pembelajaran, didapatkan bahwa metode latihan massed practice dapat meningkatkan keterampilan smash bulutangkis.
\end{abstract}

Kata kunci: Massed Practice, Keterampilan Smash, Bulutangkis. 


\section{PENDAHULUAN}

Bulutangkis adalah sebuah cabang olahraga yang memukul dan menangkis bola yang terbuat dari bulu. Inti permainan Bulutangkis adalah memasukan bola (shuttlecock) ke lapangan lawan melalui net setinggi 1,55 meter dari lantai. Jaring ini membatasi kedua bagian lapangan permainan, tempat para pemain berdiri dan melakukan gerakan-gerakan tipuan. Permainan dimulai dengan cara mengajikan bola atau service kanan ke petak service kanan lawan sehingga jalan bola menyilang. Permainan Bulutangkis ini biasanya dimainkan oleh : (1) seorang pria melawan seorang pria (tunggal putra), (2) seorang wanita melawan seorang wanita (tunggal putri), (3) sepasang pria melawan sepasang pria (ganda putra), (4) sepasang wanita melawan sepasang wanita (ganda putri), dan (5) sepasang pria / wanita melawan sepasang pria / wanita (ganda campuran).

Badminton atau bulutangkis kemudian berkembang di banyak Negara dan masuk ke Indonesia dibawa oleh orang-orang Belanda. Karena perkembangannya sangat pesat maka perlu didirikan organisasi internasinal untuk mengatur kegiatan bulutangkis internasional. "Internasional Badminton Federation" (IBF) didirikan pada tanggal 5 Juli 1934 dengan beranggotakan persatuan-persatuan bulutangkis dari beberapa Negara. Di Indonesia dibentuk organisasi induk tingkat nasional, yaitu Persatuan Bulutangkis Seluruh Indonesia (PBSI) pada tanggal 5 Mei 1951. Kemudian pada tahun 1953, Indonesia menjadi anggota IBF dan dengan demikian berhak untuk mengikuti pertandingan-pertandingan internasional.

Sebagai upaya pembinaan mutu sumber daya manusia, pendidikan jasmani atau olahraga di lembaga pendidikan formal dapat berkembang lebih pesat agar mampu menjadi landasan bagi pembinaan keolahragaan nasional. Proses pembentukan sikap dan pembangkitan motivasi harus dimulai pada usia dini. Upaya menumbuhkan budaya olahraga dalam meningkatkan kualitas manusia, dilakukan dengan jalan mewujudkan tujuan olahraga pendidikan yaitu untuk menunjang tercapainya sasaran pendidikan nasional melalui kegiatan olahraga yang telah di susun dan dijabarkan dalam kurikulum pendidikan meliputi tujuan umum maupun tujuan khusus pendidikan. Berorientasi pada pencapaian sasaran pendidikan, kegiatan olahraga pendidikan mencakup berbagai macam cabang seperti atletik, permainan, olahraga air dan olahraga beladiri. Olahraga permainan yang dilakukan dalam proses pendidikan salah satunya adalah olahraga bulutangkis.

Perkembangan olahraga bulutangkis dewasa ini sudah menjadi bagian dari olahraga yang memasyarakat terbukti di beberapa daerah banyak masyarakat yang menggemari dan memainkan olahraga ini termasuk siswaר-siswa yang ada di Kota Serang Saat ini olahraga bulutangkis sudah berkembang pesat. Hal ini bias dilihat dengan terselenggaranya berbagai turnamenturnamen yang terkait dengan cabang olahraga tersebut.

Bulutangkis merupakan salah satu olahraga yang paling terkenal di dunia. Olahraga ini menarik minat berbagai kelompok umur, berbagai tingkat keterampilan, dan pria maupun wanita memainkan olahraga ini di dalam atau di luar ruangan untuk rekreasi juga sebagai ajang persaingan. Bola bulutangkis tidak dipantulkan dan harus dimainkan di udara, sehingga permainan ini merupakan permainan cepat yang membutuhkan gerak reflek yang baik dan tingkat kebugaran yang tinggi. Pemain bulutangkis juga dapat mengambil keuntungan dari permainan ini dari segi sosial, hiburan, dan mental.

Bulutangkis merupakan olahraga yang dimainkan menggunakan net, raket, dan bola dengan teknik pemukulan yang bervariasi mulai dari yang relative lambat hingga yang sangat cepat disertai dengan gerakan tipuan. Sebenarnya, pukulan yang berlangsung dalam rally dapat saja bervariasi mulai dari 1 mil perjam pada pukulan drop hingga 200 mil per jam pada pukulan smash. Bila dimainkan oleh orang yang ahli, permainan ini di anggap sebagai permainan olahraga 
lapangan yang paling cepat di dunia. Pada kejuaraan ganda putra terbuka Amerika Serikat, satu rally terdiri dari 89 pukulan, tapi hanya berlangsung selama 1 menit. 1 pukulan bergerak melintasi net pada setiap setengah detik. Namun permainan pada pemain tunggal dan ganda dapat dikontrol untuk memenuhi kebutuhan dan kemampuan individual pada aktivitas fisik mereka.

Sejarah bulutangkis sendiri sangat menarik, sampai sekarang belum jelas siapa penemu permainan ini pertama kali. Ada yang menyebutkan jika permainan ini berasal dari India yang disebut dengan'poona' sekitartahun 1870-an. Adapula yang mengatakan bahwa Cina, sekitar 2000 tahun yang lalu terdapat permainan shuttle cock yang di Eropa dikenal dengan battle dore antara abad ke XI dan XIV. Bulutangkis dikatakan pula jika pada mulanya bernama battle dore karena permainan ini dimainkan oleh dua orang yang menepak bola kedepan (forehand) dan belakang (backhand) selama mungkin. Sampai sekarang masih menjadi tanda Tanya awal perubahan nama permainan ini

\section{METODE PENELITIAN}

Jenis penelitian ini adalah studi literatur atau penelitian kepustakaan. Menurut Mestika Zed penelitian kepustakaan adalah aktifitas yang pasif, statis, dan bias. yakni usaha memperoleh data dengan cara mendalami, mencermati, menelaah pengetahuan yang ada didalam kepustakaan (sumber Buku, Jurnal Internasional, Skripsi terdahulu dan Jurnal Nasional).

Penelitian kepustakaan atau kajian litelatur (literature riview, literature research) merupakan penelitian yang mengkaji atau meninjau secara kritis pengetahuan, gagasan, atau temuan yang terdapat di dalam tubuh litelatur berorientasi akademik (academic-oriented literature) serta merumuskan kotribusi teritis dan metodologisnya untuk topik tertentu(Cooper da taylor dalam Mohammad Imam Farisi. 2010)

\section{a. Teknik Pegumpulan Data}

Teknik pengumpulan data yang digunakan dalam penelitian ini meliputi data dari literatur maupun refrensi yang ada mengenai kendala-kendala yang sering terjadi pada pengaruh latihan massed practice terhadap keterampilan smash bulutangkis. Data yang digunakan sebagai berikut.

1. Buku

Buku merupakan buah pikiran yang berisi ilmu pengetahuan, Bahasa sederhana, menarik dan berguna untuk menunjang suatu karya ilmiah.

2. Paper dan Journal Ilmiah

Jurnal ilmiah adalah sebuah publikasi yang diterbitkan secara berkala oleh suatu organisasi profesi atau institusi akademik yang memuat artikel-artikel yang merupakan produk pemikiran ilmiah secara empiris maupun dalam bidang ilmu tertentu. Ini digunakan sebagai pendukung dalam penelitian saya.

3. Skripsi yang terdahulu dan text book Skripsi adalah suatu karya untuk menghasilkan ilmu pengetahuan atau sesuatu yang dapat dipertanggung jawabkan secara ilmiah dan dikerjakan menurut aturan dan tata cara tertentu.

4. Dokumentasi

Dokumentasi merupakan catatan peristiwa yang sudah berlalu, dapat berbentuk tulisan, gambar atau karyakarya dari seseorang. Dokumen digunakan untuk menjaring data mengenai keterampilan bulutangkis siswa. Dokumen ini yang akan digunakan dalam mengetahui pengaruh Latihan Terhadap Keterampilan Smash Bulutangkis siswa dalam mengikuti ekstrakurikuler.

\section{b. Teknik Analisis Data}

Analisis data merupakan upaya mencari dan menata secara sistematis data yang telah terkumpul untuk meningkatkan pemahaman penelitian tentang kasus yang diteliti dan mengkajinya sebagai temuan bagi orang lain. Analisis data yang 
digunakan dalam penelitian ini teknik analisis data yang digunakan dalam penelitian dengan model dari (Miles dan Huberman) yang terdiri dari tiga tahap, antara lain reduksi data, penyajian data dan penarikan kesimpulan/verifikasi yang dapat dilihat melalui gambar berikut:

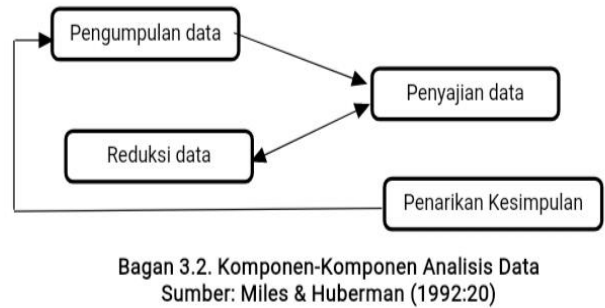

langkah pertama, mereduksi data adalah merangkum, memilih hal-hal yang pokok, memfokuskan pada hal-hal yang dianggap penting, dengan upaya mencari tema dan polanya.

langkah kedua, peneliti menyajikan (display) data. Menurut Miles dan Huberman 1984 dalam Sugiyono (2012:95) yang paling sering digunakan untuk menyajikan data dalam penelitian kualitatif adalah melalui sejumlah teks yang bersifat naratif.

langkah ketiga, peneliti menarik kesimpulan dan verifikasi sebagai jawaban terhadap rumusan masalah yang telah dituangkan sejak awal. kesimpulan merupakan kegiatan yang dilakukan dengan tujuan mencari arti, makna, penjelasan yang dilakukan terhadap data yang telah dianalisis dengan mencari halhal penting. kesimpulan ini merupakan jawaban atas permasalahan yang ingin dikaji sebagaimana dijelaskan pada identifikasi dan perumusan masalah penelitian.( Sugiyono 2016)

\section{c. Teknik Pengujian Keabsahan Data}

Dalam pengujian keabsahan data, metode literatur menggunakan istilah yang berbeda dengan penelitian kuantitatif. Keabsahan data dilakukan untuk membuktikan apakah penelitian yang dilakukan benar-benar penelitian ilmiah sekaligus untuk menguji data yang diperoleh. Uji keabsahan data dalam penelitian literature berdasarkan triangulasi data.

Menurut William Wiersma dalam Sugiyono (2012:372) Triangulasi dalam pengujian kredibilitas ini diartikan sebagai pengecekan data dari berbagai sumber dengan berbagai cara, dan berbagai waktu.

\section{HASIL DAN PEMBAHASAN}

Penelitan ini dilakukan untuk mengetahui pengaruh metode latihan massed practice terhadap keterampilan smash. Berdasarkan sumber-sumber yang relevan menunjukkan adanya pengaruh metode latihan massed practice terhadap ketepatan smash.

Berdasarkan hasil penelitian yang telah dilakukan melalui berbagai sumber yang relevan berupa jurnal maupun buku, maka peneliti menemukan bahwa metode latihan massed practice dapat meningkatkan keterampilan smash. Pernyataan ini didukung oleh berbagai penelitian terdahulu yang memperoleh peningkatan teknik keterampilan smash ketika menerapkan metode latihan massed practice.

Dilakukannya penelitian studi literatur menggunakan beberapa sumber seperti buku-buku yang relevan dengan penelitian yang dilakukan, jurnal-jurnal maupun skripsi terdahulu yang berkaitan. Hal ini sesuai dengan teknik pengujian keabsahan data. Pengujian keabsahan data dilakukan untuk membuktikanapakah penelitian yang dilakukan benar-benar penelitian ilmiah sekaligus untuk menguji data yang diperoleh. Uji keabsahan data dalam penelitian literatur berdasarkan triangulasi data..

Teknik pengujian keabsahan data dalam penelitian kualitatif, salah satunya menggunakan triangulasi. Triangulasi yang digunakan adalah triangulasi sumber. Beberapa sumber yang digunakan yaitu buku-buku yang berkaitan dengan variabel $\mathrm{x}$ dan y dalam penelitian, jurnal-jurnal dan juga skripsi Triangulasi sumber difokuskan pada data penelitian yang telah dilakukan sebelumnya. 
Kesimpulan dari hasil penelitian ini dapat mengandung pengembangan ide yang lebih luas jika dikaji pula tentang implikasi yang ditimbulkan. Atas dasar kesimpulan yang telah diambil, dapat dikemukakan implikasinya, Secara umum dapat dikatakan bahwa metode latihan massed practice, dapat mempengaruhi peningkatan kemampuan keterampilan smash bulutangkis. Metode pembelajaran massed practice memberikan pengaruh yang signifikan dalam meningkatkan kemampuan keterampilan smash bulutangkis. Metode latihan tersebut dapat dipergunakan, upaya meningkatkan kemampuan keterampilan smash bulutangkis. Berkenaan dengan penerapan bentuk metode latihan massed practice untuk dapat meningkatkan kemampuan keterampilan smash bulutangkis,

\section{Saran}

Berdasarkan kesimpulan di atas, dapat diusulkan saran yang diharapkan akan bermanfaat bagi penelitian selanjutnya:

1. Bagi Instansi Terkait

Dinas Pendidikan dan Sekolah untuk senantiasa meningkatkan

Sumber Daya Manusia, sarana dan prasarana maupun perangkat dalam pembelajaran tentang konsep-konsep pembelajaran yang menarik perhatian siswa.

2. Bagi Siswa

Siswa hendaknya dapat lebih meningkatkan kualitas geraknya melalui metode latihan massed practice, sehingga siswa dapat melakukan keterampilan smash dengan kualitas yang baik untuk mendukung penampilannya,

3. Bagi Peneliti Selanjutnya

Bagi peneliti selanjutnya yang tertarik untuk melakukan kajian di bidang yang sama dapat menambah variabel independen maupun dependen yang memiliki kemungkinan pengaruh terhadap keterampilan smash. Peneliti selanjutnya disarankan untuk menambah jumlah sumber referensi sehingga penelitian dapat digeneralisasikan dengan baik.

\section{DAFTAR PUSTAKA}

Apta Mylsiduyi, Febi Kurniawan. (2015). Ilmu kepelatihan Dasar. Bandung: Alfabeta.

Arikunto Suharsimi.(2013) Prosedur Penelitian Suatu Pendekatan Praktik. Jakarta : Rineka Cipta

Azmin Sham Rambely,dkk.(2005) The Analysis of The Jumping Smash In The Game Of Badminon. centre Of Mathematical Sciences, Faculty Of Science \& Technology, National University Of Malaysia, Bangi, Selangor, West Malaysia 'Biomedical Engineering Department, Faculty Of Engineering, University Of Malaya.Kuala Lumpur, West Malaysia.

Diantama, Suarifqi. (2017). Metode Penelitian Pendidikan. Bandung: Pustaka Rahmat

Grice, Toni. (2007) Petunjuk Praktis Untuk

Pemula Dan Lanjut Permainan Bulutangkis. Jakarta : PT Raja Grafindo Persada

Habyf, Bhulloh Muhammad. (2015). Pengaruh Metode Latihan Antara Distributed Practice Dan Massed Practice Terhadap Kemampuan Servis Panjang Bulutangkis Pada Siswa Smk Negeri 1 Grogol Tahun Ajaran 2014/2015, dari

http://simki.unpkediri.ac.id/mahasiswa/fi le $\operatorname{artikel/2015/11.1.01.09.0319.pf}$

Harsono. (2018). Kepelatihan Olahraga, Teori Dan Metodologi. Bandung: PT Remaja Rosda Karya

Hermawan, Hedi Ardiyanto. 2016. TahapTahap Latihan. (http://id.scribd.com/2016//). Diunduh tanggal 20 Februari 2020 jam 23.10

Melfianora. (2017) Penulisan Karya Ilmiah Dengan Studi Litaratur. Pekanbaru

Ni'mah Tashilatul Ismi dan Deli Mateus (2017) Buku Pintar Bulutangkis. Jakarta : Anugrah 